\title{
Conflitos legais e impactos ambientais no município de Extremoz, RN, Nordeste do Brasil
}

\author{
Legal conflicts and environmental impacts in the municipality of Extremoz, RN, \\ Northeast of Brazil.
}

\author{
BARROS ${ }^{1}$, J. D.; MONTEIRO², T. R. R.; SILVA ${ }^{3}$, C. C. L.; ARAÚJO ${ }^{4}$, I. S.; MELLO ${ }^{5}$, M. T. C.; \\ DICKSON $^{6}$, D.; NASCIMENTO ${ }^{7}$, S. R. V.; LIMA $^{8}$, Z. M. C. \\ jocilene_db@yahoo.com.br
}

\begin{abstract}
Resumo
O estudo objetivou analisar os conflitos legais em áreas protegidas e impactos ambientais no município de Extremoz-RN, zona costeira do nordeste brasileiro. Os procedimentos metodológicos envolveram a pesquisa bibliográfica, coleta de dados secundários, pesquisa de campo e elaboração cartográfica. Como impactos ambientais decorrentes das diversas formas de ocupação do solo pode-se citar o desmatamento e queima da vegetação de mata ciliar, ocorrência de processos erosivos e assoreamento em corpos d'água e possível perda de biodiversidade pela extração de areia. Em relação aos conflitos ambientais legais, constatou-se que $11 \%$ das áreas protegidas estão ocupadas por atividades antrópicas.
\end{abstract}

Palavras-chave: conflitos legais, impactos ambientais, ocupação do solo.

\begin{abstract}
The study aimed to analyze the legal conflicts in protected areas and environmental impacts in the municipality of Extremoz-RN, coastal area of northeastern Brazil. The methodological procedures involve the bibliographic research, secondary data collection, field survey and cartographic elaboration. As environmental impacts of various forms of occupation of land can be cited deforestation and burning of gallery forest, occurrence of erosion and siltation of water bodies and possible loss of biodiversity through the sand extraction. In relation to legal environmental conflicts, was found that $11 \%$ of protected areas are occupied by human activities.
\end{abstract}

Keywords: legal conflicts, environmental impacts, occupation of land.

\section{INTRODUÇÃO}

A zona costeira brasileira abrange $26,6 \%$ da população do país, uma vez que a densidade demográfica no litoral é cinco vezes maior do que a média nacional (IBGE, 2015). Nesta área ocorrem atividades e usos que lhe são próprios, devido à localização na faixa litorânea, em contato com o continente e o oceano, e por possuir uma série de atributos singulares que vão qualificá-la como uma situação geográfica ímpar. Por causa da sua complexidade, exigem diversos enfoques

\footnotetext{
${ }^{1}$ Jocilene Dantas Barros, Geógrafa autônoma, Natal-RN, Brasil.

${ }^{2}$ Thereza Rachel Rodrigues Monteiro, Programa de Pós-graduação em Geografia, Universidade Federal do Rio Grande do Norte, Natal-RN, Brasil.

${ }^{3}$ Cleanto Carlos Lima da Silva, Programa de Pós-graduação em Geografia, Universidade Federal do Rio Grande do Norte, Natal RN, Brasil.

${ }^{4}$ Isailma da Silva Araújo, Programa de Pós-graduação em Geografia, Universidade Federal do Rio Grande do Norte, Natal - RN, Brasil.

${ }^{5}$ Mariana Torres Correia Mello, Programa de Pós-graduação em Geografia, Universidade Federal do Rio Grande do Norte, NatalRN, Brasil.

${ }^{6}$ David Dickson, Mestre em Geografia, Université Paris 8, França.

${ }^{7}$ Sergio Roberto Vidal do Nascimento, Professor do Governo do Estado, Escola Estadual Desembargador Floriano Cavalcanti, Natal-RN, Brasil.

${ }^{8}$ Zuleide Maria Carvalho Lima, Departamento de Geografia, Universidade Federal do Rio Grande do Norte, Natal - RN, Brasil.
} 
integradores dos domínios socioeconômicos e ecológicos, sendo analisado nas múltiplas escalas espaciais e temporais (AMARO; SANTOS; SOUTO, 2012).

Extremoz, por sua vez, é um município localizado no litoral Leste do estado do Rio Grande do Norte, Nordeste do Brasil, que possui uma diversidade de atividades socioeconômicas, com destaque para a agropecuária e o turismo, além de ecossistemas de grande relevância ambiental, relativos às lagoas, dunas e manguezais. A partir deste contexto, faz-se necessário analisar os impactos ambientais e os conflitos legais relativos às áreas protegidas no município de Extremoz$\mathrm{RN}$, visando contribuir para uma gestão e planejamento integrado.

Neste sentido, os objetivos específicos desta pesquisa são: caracterizar os tipos de ocupação e cobertura do solo no município, identificar as áreas ambientais protegidas e as ocupações humanas conflitantes, além de investigar os impactos ambientais resultantes da ocupação no município de Extremoz.

A análise dos conflitos com as legislações de proteção ambiental e os impactos no município de Extremoz-RN, é pautada, portanto, na visão sistêmica, pois permite a compreensão das interrelações entre elementos e o ambiente. Para tanto, Tricart (1977, p.19) aponta a relação que essa relação sistêmica é "capaz de ensejar uma atuação eficaz sobre o meio". Também possibilita a visão sistêmica da Geografia em atividades públicas e privadas expressas na "realização dos diagnósticos, zoneamentos e avaliação de impactos ambientais" (SALES, 2004, p. 130), tendo uma contribuição considerável na perspectiva da sustentabilidade e melhoria da qualidade ambiental dos espaços. Além disso, vê-se a necessidade de compreender a legislação ambiental que determina diretrizes para o ordenamento do território, auxiliado pelo mapeamento da área.

\section{METODOLOGIA}

Para alcançar esses objetivos foram executados procedimentos técnicos que envolveram a revisão bibliográfica, coleta de dados demográficos, arquivos vetoriais, imagens de satélite e elaboração de mapas de ocupação, cobertura do solo e conflitos ambientais legais no município, bem como uma análise dos impactos ambientais, melhor explanados na metodologia.

\subsection{Caracterização socioambiental do município}

O município de Extremoz está localizado no estado do Rio Grande do Norte e integra a Região Metropolitana de Natal (RMN), com cerca de $128 \mathrm{~km}^{2}$ de área territorial. (Figura 1). O acesso ao município de Extremoz é feito principalmente pelas rodovias BR-101 e RN-302 e RN- 
307, além de estradas secundárias e vicinais. Extremoz está distante 23,5 km de Natal, capital do referido estado.
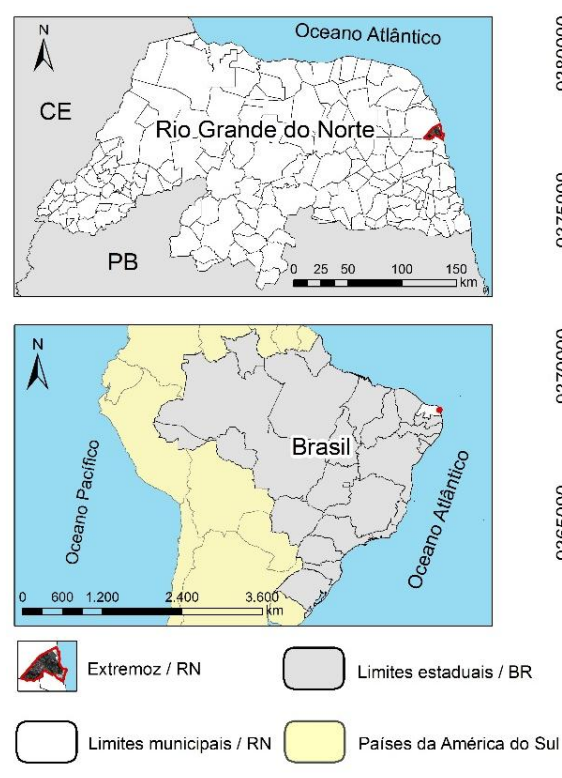

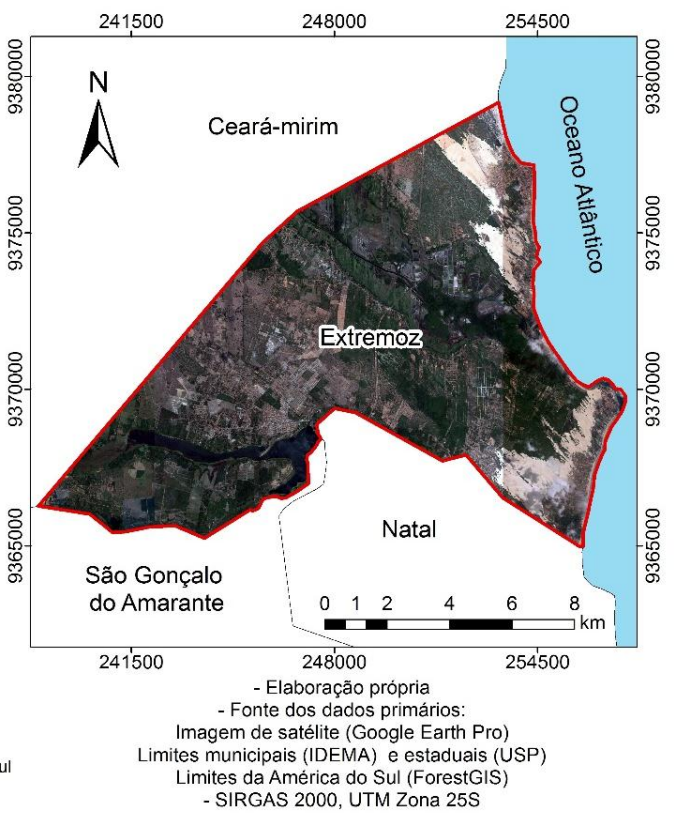
- SIRGAS 2000, UTM Zona $25 S$

Figura 01. Mapa de localização do município de Extremoz-RN. Fonte: elaboração dos autores.

Tratando-se dos aspectos demográficos do município de Extremoz, a população correspondeu a aproximadamente 24.569 habitantes em 2010 e posteriormente estimada em 27.525 habitantes para 2015, de acordo com o Instituto Brasileiro de Geografia e Estatística (IBGE), ocupando assim a décima nona posição entre as cidades do estado do Rio Grande do Norte. O município alcançou um crescimento relativo de 25,53\% na década 2000, na qual registrava 19.572 habitantes no ano 2000, segundo dados do censo demográfico do IBGE (2010).

Ainda segundo IBGE (2010), quase 6.900 domicílios estão estabelecidos neste município. Um total de 90,79\% dos domicílios são atendidos pelo serviço de coleta de lixo, sendo 93,88\% o percentual de domicílios ligados à rede geral de abastecimento de água. A proporção de domicílios com existência de energia elétrica alcançou a marca de 99,10\%. Em contrapartida, apenas 2,96\% dos domicílios estão ligados à rede geral de esgoto (ATLAS DO DESENVOLVIMENTO HUMANO, 2010). Esses dados são expressos na Figura 2. 


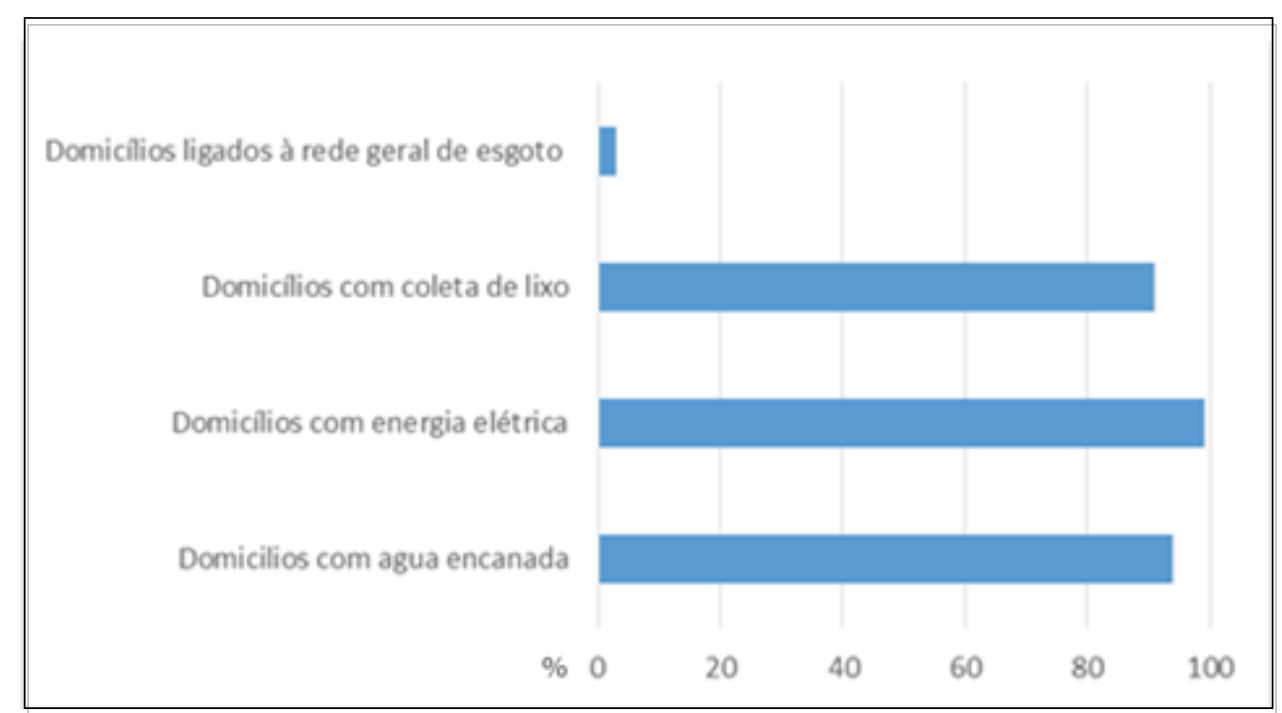

Figura 02. Indicadores de habitação do município de Extremoz/RN. Fonte: adaptado do Atlas do Desenvolvimento Humano (2010).

A atividade turística apresentou uma importante intensificação no município a partir da implementação do Programa de Desenvolvimento do Turismo no Nordeste (PRODETUR), desde 1997. Atualmente, esta atividade organiza-se em torno de seis praias no município: Redinha Nova, Santa Rita, Genipabu, Barra do Rio, Grançandu e Pitangui.

Os principais atrativos turísticos são o Aquário Natal, passeio de dromedários pelas dunas, passeio de buggy (típico carro com tração), passeio de jegue, passeio de caiaque, travessia de balsa, descidas radicais no "aerobunda", visitas as lojinhas com produtos artesanais, visitas as lagoas e cachoeiras, entre outras. As infraestruturas turísticas da faixa litorânea do município de Extremoz são consideradas equipamentos de pequeno e médio portes.

Em 2008, contavam-se 24 hotéis, chalés, pousadas e resorts nas praias de Redinha Nova, Santa Rita e Genipabu (NASCIMENTO, 2008). Recentemente, o Instituto de Desenvolvimento Sustentável e Meio Ambiente do Rio Grande do Norte (IDEMA, 2013) identificou 26 meios de hospedagem (pensões e hotéis) estabelecidos no município de Extremoz.

O município tem áreas agropecuárias que ocupam mais de $30 \mathrm{~km}^{2}$, ou seja, quase $24 \%$ da área do município. É a prática de agricultura permanente que domina nessa área, principalmente pela produção de banana.

Algumas dessas áreas agropecuárias praticam culturas temporárias, geralmente para a agricultura da mandioca e do feijão. Além disso, as unidades agropecuárias vêm desenvolvendo uma agricultura permanente ou temporária ligada a um sistema de preparação do solo: algumas 
praticam conjuntamente técnicas de aração $^{1}$ e gradagem ${ }^{2}$, embora muitas praticam diretamente a gradagem (IBGE, 2010).

Em relação aos aspectos fisiográficos do Município, a vegetação de Extremoz-RN pertence ao bioma da Mata Atlântica, presente ao longo da costa litorânea do Brasil.

De acordo com IDEMA (2013, p. 07), existem dois tipos de formações vegetais no município: a formação tabuleiros litorâneos próximo às áreas de intervenção humana, bem como, o ecossistema de manguezal, um "sistema ecológico costeiro tropical dominado por espécies vegetais - mangues e animais típicos aos quais se associam outras plantas e animais, adaptadas a um solo periodicamente inundado pelas marés, com grande variação de salinidade”. Destaca-se também ao longo das dunas a vegetação de restinga e plantas aquáticas de água doce nas margens das lagoas (ECOPLAM, 2006).

Quanto aos aspectos geológicos e geomorfológicos, o município de Extremoz está inserido principalmente na área de abrangência da Formação Barreiras, com Idade do Terciário-Superior, onde predominam arenitos finos a médios, ou conglomeráticos, com intercalações de siltitos e argilitos, dominantemente associados a sistemas fluviais. As rochas da Formação Barreiras estão recobertas por Paleocascalheiras, compostos paraconglomerados com seixos de quartzo, sílex e fragmentos líticos de matriz areno-argilosa avermelhada (IDEMA, 2013).

Próximas ao litoral encontram-se Paleodunas ou Dunas Fixas formadas de areias bem selecionadas, amareladas, inconsolidadas ou parcialmente consolidadas, que foram transportadas pela ação dos ventos (eólica), formando cordões, atualmente fixados por vegetação. Acompanhando a faixa litorânea estão Depósitos de praias de origem marinha remodelados por ventos, que são compostos de areias finas a grossas, com níveis de cascalho, associadas às praias atuais e dunas móveis, arenitos e conglomerados com cimento carbonático, definindo cordões de beach rocks. No vale do rio Ceará-Mirim encontram-se Depósitos aluvionares, formados por areias e cascalhos, com intercalações pelíticas, associados aos sistemas fluviais atuais, formando uma planície fluvial, área plana resultante da acumulação fluvial sujeita a inundações periódicas (IDEMA, 2013).

Próximo ao litoral na região do estuário do Rio Ceará-Mirim encontra-se a Planície fluviomarinha formada por uma área plana resultante da combinação de processos de acumulação fluvial e marinha, geralmente sujeitas inundações periódicas, com vegetação de mangues, caracterizada como Depósitos de planícies e canais de marés compostos por pelitos arenosos,

\footnotetext{
${ }^{1}$ Se referente a aração do solo, é um processo que revolve a terra com o objetivo de descompactá-la e, assim, viabilizar um melhor desenvolvimento das raízes das plantas (DICIONÁRIO PORTUGUÊS, 2016).
} 
carbonosos ou carbonáticos. Sobre os Tabuleiros próximos à sede municipal, os cursos d'água do Rio Mudo e Guajiru foram barrados por areias dos campos dunares dando origem a Lagoa de Extremoz (IDEMA, 2013). Os solos predominantes são classificados como Areias Quartzosas Distróficas de fertilidade natural muito baixa, textura arenosa, excessivamente drenados, profundos e localizados em relevo plano (IDEMA, 2013).

A área do município de Extremoz está inserida no domínio do clima Aw`, clima tropical chuvoso quente com verão seco, segundo a classificação climática de W. Köppen. Além disso, esta área é influenciada pela Zona de Convergência Intertropical (ZCIT), com chuvas de outono nos meses de março, abril e maio e nos meses de inverno, junho, julho e agosto (AGUIAR, 2013).

Os ventos que ocorrem nessa região são fracos a moderados de $2,57 \mathrm{~m} / \mathrm{s}$ a $5,14 \mathrm{~m} / \mathrm{s}$ e recebem influência da Massa Equatorial Atlântica, ventos alísios de noroeste, e da Massa Tropical Atlântica, ventos alísios de sudeste, predominantes na região. Entre os meses de agosto a outubro os ventos alísios de sudeste apresentam maiores velocidades com médias de $5 \mathrm{~m} / \mathrm{s}$ sendo responsáveis pela elevação da evapotranspiração e ressecamento da superfície da vegetação (AGUIAR, 2013).

A precipitação média anual no município de Extremoz é de $1.678,5 \mathrm{~mm}$, segundo dados da Empresa de Pesquisa Agropecuária do Rio Grande do Norte (EMPARN, 2015), observados entre os anos de 1986 a 2014 (Figura 3). A maior média de precipitação ocorreu em 1974 com 2.465,8 mm, e a menor média em 1983, com 645,5 mm. As precipitações médias mensais demonstram que os meses de fevereiro a agosto são os mais chuvosos com médias de precipitação acima de $100 \mathrm{~mm}$, enquanto que de setembro a dezembro a média é abaixo dos $30 \mathrm{~mm}$. O mês mais chuvoso do período foi julho de 1998 com precipitação de 698,4 mm (INMET, 2015; EMPARN, 2015).

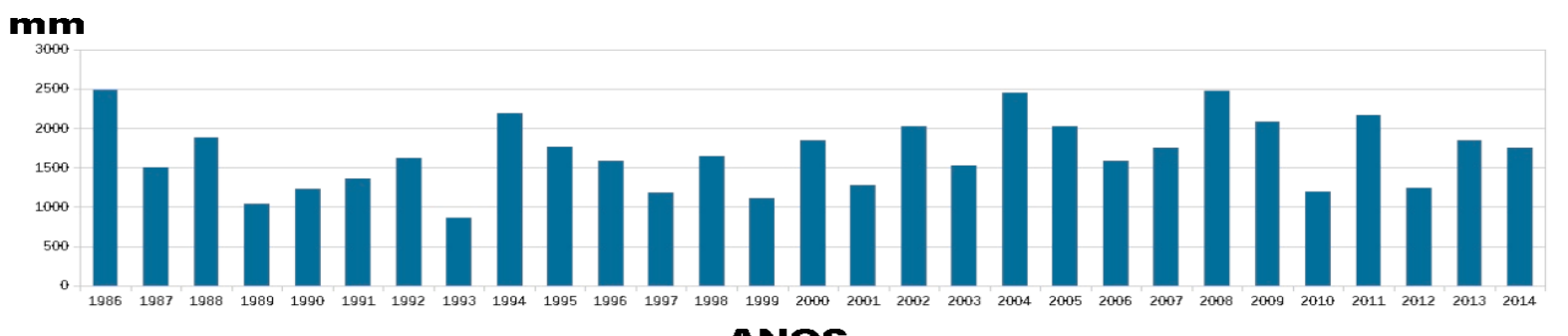

ANOS

Figura 03. Precipitação anual em Extremoz-RN de 1986 à 2014. Fonte: EMPARN (2015).

\footnotetext{
2 Gradagem é a etapa de preparação do solo para cultivo agrícola posterior à aração. Após a aração, o solo ainda poderá conter muitos torrões, o que dificultaria a emergência das sementes e o estabelecimento das culturas. Com a utilização do implemento grade, os torrões são desfeitos e a superfície do solo torna-se mais uniforme (DICIONÁRIO PORTUGUÊS, 2016).
} 
A umidade relativa do ar no município de Extremoz atinge valor médio anual de $80 \%$. A insolação média anual é de 2800 horas, com maior intensidade nos meses de outubro, novembro e dezembro, sendo outubro o mês com maior insolação média, 290 horas. As temperaturas chegam frequentemente acima dos $30^{\circ} \mathrm{C}$, e a média diária é de $25,4^{\circ} \mathrm{C}$. Em média a amplitude térmica é de $8,4^{\circ} \mathrm{C}$ (AGUIAR, 2013).

49,45\% do território municipal está inserido na Bacia Hidrográfica do Rio Ceará-Mirim, 22,03\% na Bacia Hidrográfica do Rio Doce e 28,52\% na Faixa Litorânea Leste de Escoamento Difuso. Os rios principais são o Guajiru, do Mudo, Doce e Ceará-Mirim. As principais Lagoas são Extremoz e Guamoré (SEMARH, 2008). As águas subterrâneas estão armazenadas no Aquífero Barreiras que se apresenta confinado, semiconfinado e livre em algumas áreas, com águas de excelente qualidade química, com baixos teores de sódio, podendo ser utilizada praticamente para todos os fins. O Aquífero Aluvião apresenta-se disperso sendo constituído pelos sedimentos geralmente arenosos depositados nos leitos e terraços dos rios e riachos de maior porte. Estes depósitos caracterizam-se pela alta permeabilidade, boas condições de realimentação e uma profundidade média em torno de sete metros. A qualidade da água geralmente é boa e pouco explorada (IDEMA, 2013).

\subsection{Procedimentos metodológicos}

Diante dos objetivos específicos estabelecidos para a realização desse estudo foi necessária a utilização de Geotecnologias, definidas como um "conjunto de tecnologias para coleta, processamento, análise e oferta de informações com referência geográfica" (ROSA, 2005, p. 81). Dessa forma, para caracterizar os tipos de ocupação e cobertura do solo no município utilizou-se um mosaico de imagens do Google Earth PRO (anos 2014 e 2015) para a interpretação visual dos alvos da superfície terrestre no município de Extremoz.

Com a fotointerpretação foi possível mapear as diversas classes de ocupação e cobertura do solo através do processo de vetorização no SIG ArcGIS 10.1, tendo como base cartográfica a geomorfologia da área estudada e o limite municipal de Extremoz (IDEMA, 2006) e tendo como escala de mapeamento 1:10.000. Essa caracterização dos tipos de ocupação e cobertura do solo existentes na área de estudo foi elaborada com base nas unidades geomorfológicas, análise da imagem de satélite e pesquisa de campo em treze (13) pontos amostrais.

A identificação das áreas ambientais protegidas e as ocupações humanas conflitantes foi elaborada com base no mapa de ocupação e cobertura do solo de Extremoz e na pesquisa de campo, realizada no dia 06 de novembro de 2015. Com os dados vetoriais de ocupação e cobertura do solo, 
juntamente com as áreas ambientais protegidas (IDEMA, 2006), foi possível gerar um mapa temático de conflitos ambientais legais no município. Também para gerar esse mapa de conflitos ambientais foi aplicada a técnica de intersecção de mapas.

A validação dos mapeamentos foi realizada através de visita in loco, com o GPS de navegação Garmim s64, caderneta de campo para observações e câmera fotográfica para o registro das classes de ocupação de cobertura do solo, dos impactos e conflitos ambientais legais.

Para investigar os impactos ambientais resultantes da ocupação no município de Extremoz, foi realizado uma caracterização socioeconômica. Essa caracterização, foi elaborada com base no banco de dados do censo do IBGE realizado em 2010 e no Atlas de Desenvolvimento Humano do Brasil (2013), a fim de obter informações sobre as condições da população, infraestrutura e moradia da área estudada.

As legislações vigentes utilizadas foram: a Constituição Federal Art. 255, Resolução CONAMA n ${ }^{\circ} 303$, de 20 de março de 2002 que foi alterada pela Resolução n 341 de 2003, Decreto Estadual nº 12.620 de 1995, Plano Diretor de Desenvolvimento Urbano - Extremoz Lei n493/2006 no Artigo $65, \S 1^{\circ}$ - Áreas especiais e Lei $n^{\circ} 9.254$ de 2009. Essas leis serviram como base para o enquadramento legal das unidades de conservação e o entendimento dos conflitos e impactos ambientais presentes no município de Extremoz-RN. Nesse contexto, a Figura 4 apresenta a estrutura de execução dos procedimentos metodológicos no mapeamento dos impactos e conflitos ambientais legais em Extremoz-RN.

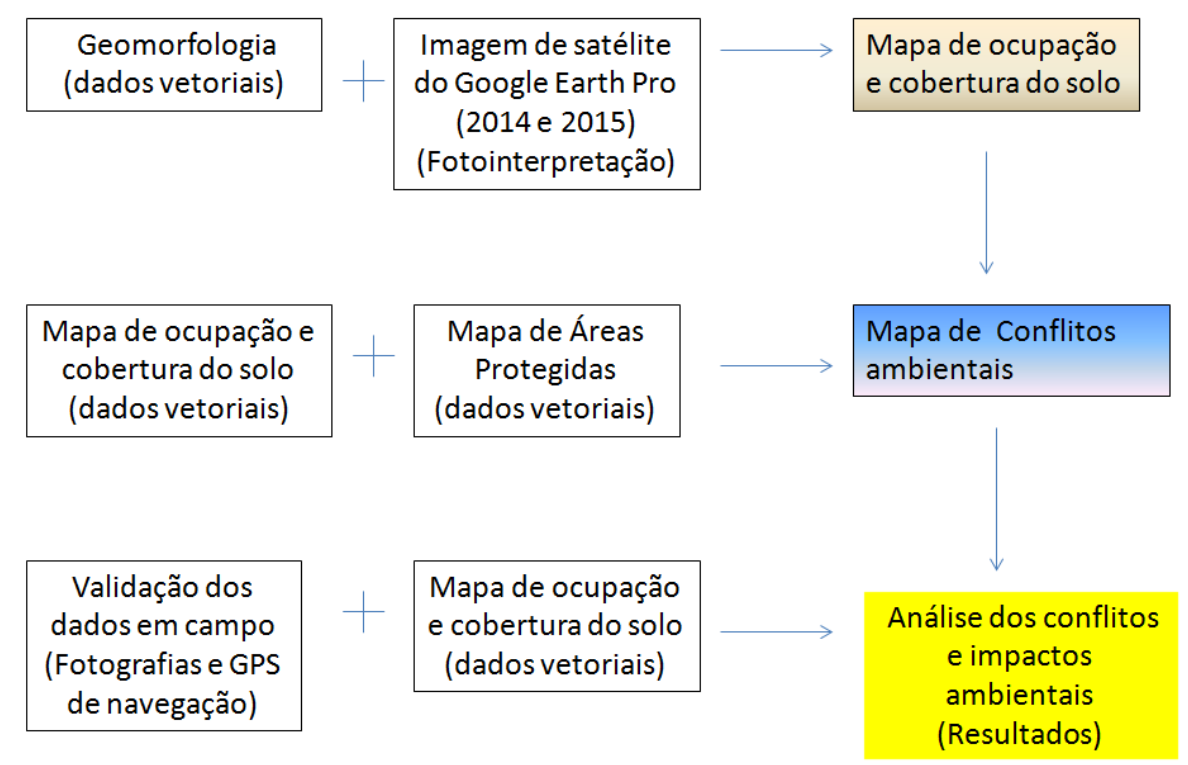

Figura 04. Fluxograma com a estrutura de execução dos procedimentos metodológicos no mapeamento dos impactos e conflitos ambientais legais em Extremoz-RN. Fonte: elaboração dos autores. 


\section{RESULTADOS E DISCUSSÃO}

Para a caracterização dos tipos de ocupação e cobertura dos solos existentes na área de estudo elaborou-se um mapa com onze classes, subdivididas em atividades e ocupações antrópicas (agropecuária, área edificada, área de expansão de edificação e carcinicultura) e aspectos geoambientais do município (área alagada, cobertura arenosa, corpos d'água, manguezal, mata ciliar, vegetação de restinga e vegetação de tabuleiro). As áreas de cada classe foram calculadas em $\mathrm{km}^{2}$ e porcentagem, expressas na Figura 05 e Tabela 01.

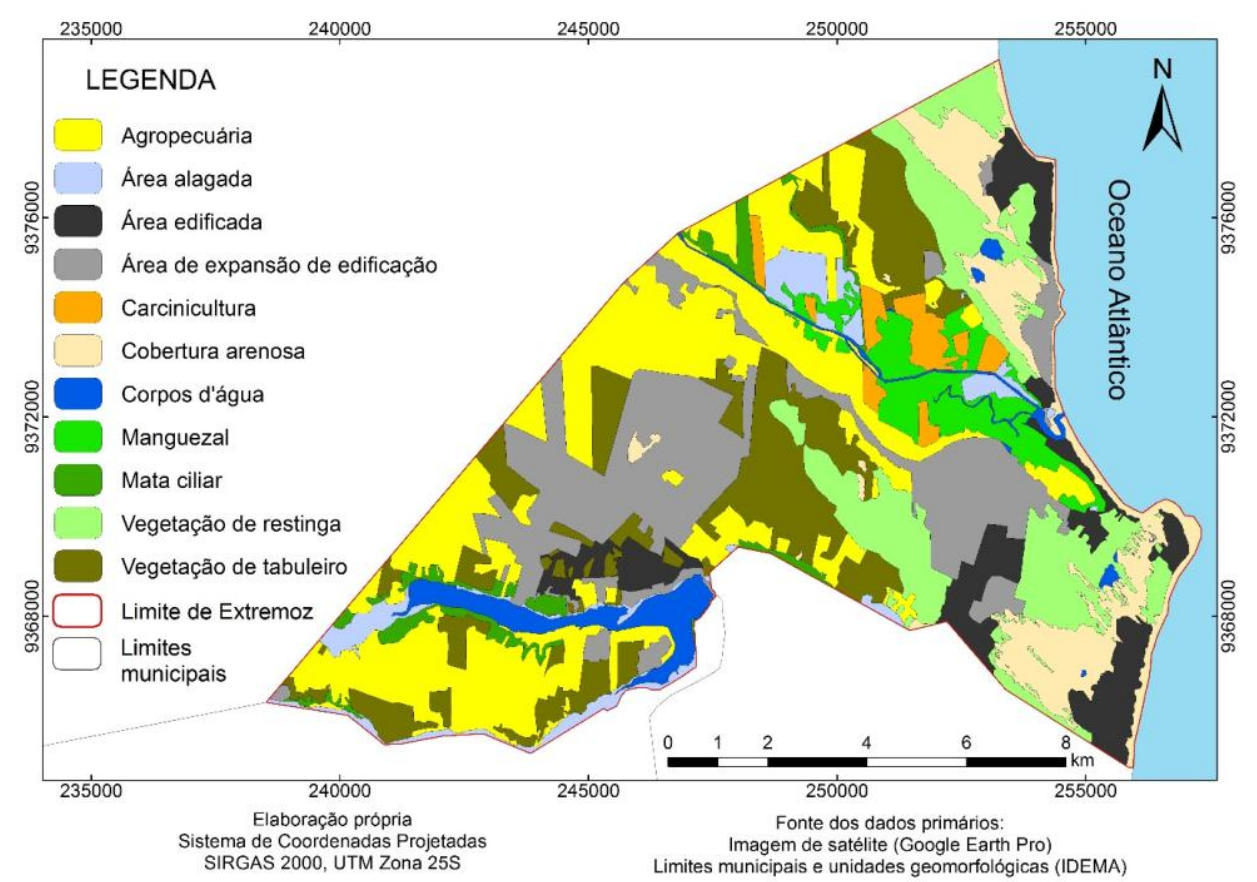

Figura 05. Mapa de ocupação e cobertura do município de Extremoz-RN. Fonte: elaboração dos autores.

Tabela 01. Classes de ocupação e cobertura do solo mapeadas no município de Extremoz-RN. Fonte: elaborada pelos autores.

\begin{tabular}{|l|l|l|l|}
\hline \multicolumn{3}{|c|}{ Classes de ocupação e cobertura do solo } \\
\hline 1 & Agropecuária & Área $\left(\mathrm{km}^{2}\right)$ & Porcentagem $(\%)$ \\
\hline 2 & Área alagada & 30,57 & 23,87 \\
\hline 3 & Área edificada & 5,02 & 3,92 \\
\hline 4 & Área de expansão de edificação & 9,42 & 7,36 \\
\hline 5 & Carcinicultura & 22,09 & 17,25 \\
\hline 6 & Cobertura arenosa & 2,83 & 2,21 \\
\hline 7 & Corpos d'água & 10,81 & 8,44 \\
\hline 8 & Manguezal & 4,57 & 3,56 \\
\hline 9 & Mata ciliar & 5,90 & 4,60 \\
\hline 10 & Vegetação de restinga & 3,18 & 2,48 \\
\hline 11 & Vegetação de tabuleiro & 14,66 & 11,44 \\
\hline
\end{tabular}




\section{TOTAL}

128,09

100,00

A classe agropecuária corresponde à $23,87 \%$ da área do município e envolve agricultura temporária e permanente, bem como áreas de pastagem cobertas por vegetação herbácea, sendo a ocupação de maior abrangência espacial no município. A área edificada refere-se às áreas onde há um maior adensamento urbano e, geralmente, ausência de áreas de solo exposto, totalizando 7,36\%. A classe área de expansão de edificação, contudo, é composta por áreas desmatadas para construção de novos conjuntos habitacionais e zonas residenciais de menor expressão espacial $(17,25 \%)$, e associadas a estas, pequenas áreas de produção agrícola. Em áreas próximas ao ecossistema manguezal encontra-se a classe carcinicultura, vinculada aos viveiros de camarão que totalizam $2,21 \%$ da área de estudo, composta por viveiros desativados e atualmente em atividade.

No que se refere à mata ciliar, se localiza nas margens dos rios e lagoas em áreas não influenciadas pela maré, contabilizando $2,48 \%$. A classe manguezal corresponde ao ecossistema localizado na planície flúvio-marinha $(4,60 \%)$, na direção Nordeste do município. A vegetação de restinga, fixadora de dunas, compreende $11,44 \%$ próxima ao litoral do município, enquanto que a vegetação de tabuleiro $(14,87 \%)$ compreende uma variedade de espécies de diferentes portes, que estão sobre a unidade geomorfológica tabuleiro e é diretamente afetada pela expansão urbana do município.

As áreas alagadas correspondem à 3,92\% da ocupação e cobertura de Extremoz e estão presentes nas margens de rios, lagoas e na planície flúvio-marinha não ocupada por espécies de mangue. Em relação aos corpos d'água, considera-se como pertencentes à essa classe as lagoas e rios do município (3,56\%), com destaque para o rio Ceará-Mirim à Nordeste e para a lagoa de Extremoz no Sudoeste da área de estudo. Por fim, a classe cobertura arenosa refere-se aos solos expostos que cobrem as dunas móveis, a zona de praia de Extremoz e áreas desmatadas do município $(8,44 \%)$.

\subsection{Conflitos legais: legislação ambiental versus ocupação e cobertura em Extremoz-RN}

O crescimento das cidades nas últimas décadas tem sido responsável pelo aumento da pressão das atividades antrópicas sobre os recursos naturais e, no decorrer desse tempo, podemos constatar o progresso dos centros urbanos, à custa de degradação ambiental, com a consequente diminuição da oferta de recursos naturais. Nesse sentido o poder público tem atualmente desenvolvido políticas de controle que possibilitem frear o desenvolvimento econômico atual que não esteja em sintonia com o desenvolvimento sustentável. 
O trabalho buscou identificar as contradições entre o que propõe a legislação ambiental e o que realmente acontece no município de Extremoz-RN. Para isso, foi elaborado o Quadro 01 com o enquadramento legal, que contribuiu para espacializar as áreas protegidas do município, levando em conta legislações pertinentes desde o âmbito Federal ao municipal.

\begin{tabular}{|c|c|c|}
\hline $\begin{array}{l}\text { Legislações } \\
\text { Pertinentes }\end{array}$ & Descrição da Legislação & Relação com a área \\
\hline \multirow[b]{2}{*}{$\begin{array}{l}\text { Constituição } \\
\text { Federal Art. } 225 .\end{array}$} & $\begin{array}{l}\text { Todos têm direito ao meio ambiente } \\
\text { ecologicamente equilibrado, bem de uso } \\
\text { comum do povo e essencial à sadia } \\
\text { qualidade de vida, impondo-se ao poder } \\
\text { público e à coletividade o dever de defendê- } \\
\text { lo e preservá-lo para as presentes e futuras } \\
\text { gerações. }\end{array}$ & $\begin{array}{l}\text { A criação do art. 225, estabeleceu o } \\
\text { direito ao meio ambiente e o dever de } \\
\text { tutela, além de estender a } \\
\text { responsabilidade pela manutenção do } \\
\text { ambiente saudável a população e ao } \\
\text { poder público. }\end{array}$ \\
\hline & $\begin{array}{l}\text { VII, §4 } 4^{\circ} \text {, Floresta Amazônica brasileira, a } \\
\text { Mata Atlântica, a Serra do Mar, o Pantanal } \\
\text { Mato-Grossense e a Zona Costeira são } \\
\text { patrimônio nacional, e sua utilização far-se- } \\
\text { á, na forma da lei, dentro de condições que } \\
\text { assegurem a preservação do meio ambiente, } \\
\text { inclusive quanto ao uso dos recursos } \\
\text { naturais. }\end{array}$ & $\begin{array}{l}\text { Impôs a responsabilização pela } \\
\text { degradação a todos os poluidores, } \\
\text { estejam eles agindo por ação ou por } \\
\text { omissão, desde que se relacionem com } \\
\text { o evento danoso ao meio ambiente. }\end{array}$ \\
\hline \multirow[b]{2}{*}{$\begin{array}{l}\text { Resolução } \\
\text { CONAMA no } 303 \text {, } \\
\text { de } 20 \text { de março de } \\
2002 . \\
\text { Alterada pela } \\
\text { Resolução no } 341 \text {, de } \\
2003 .\end{array}$} & $\begin{array}{l}\text { Dispõe sobre parâmetros, definições e } \\
\text { limites de Áreas de Preservação Permanente. }\end{array}$ & $\begin{array}{l}\text { Alterada pela Resolução } \mathrm{n}^{\circ} 341 \text {, de } \\
2003 \text {, essas alterações envolvem três } \\
\text { pontos essenciais, o primeiro diz } \\
\text { respeito à APP de margem de rio, com a } \\
\text { alteração do conceito de "nível mais } \\
\text { alto"; o segundo à metodologia para } \\
\text { medição das áreas de topo de morros, e } \\
\text { o terceiro que retira do texto a parte que } \\
\text { define como APPs, nas restingas, uma } \\
\text { faixa de } 300 \text { metros a partir da linha de } \\
\text { preamar máxima. }\end{array}$ \\
\hline & $\begin{array}{l}\text { VII - manguezal: ecossistema litorâneo que } \\
\text { ocorre em terrenos baixos, sujeitos à ação } \\
\text { das marés, formado por vasas lodosas } \\
\text { recentes ou arenosas, às quais se associa, } \\
\text { predominantemente, a vegetação natural } \\
\text { conhecida como mangue, com influência } \\
\text { flúvio-marinha, típica de solos limosos de } \\
\text { regiões estuarinas e com dispersão } \\
\text { descontínua ao longo da costa brasileira, } \\
\text { entre os estados do Amapá e Santa Catarina; } \\
\text { VIII - restinga: depósito arenoso paralelo a } \\
\text { linha da costa, de forma geralmente } \\
\text { alongada, produzido por processos de } \\
\text { sedimentação, onde se encontram diferentes } \\
\text { comunidades que recebem influência } \\
\text { marinha, também consideradas comunidades } \\
\text { edáficas por dependerem mais da natureza } \\
\text { do substrato do que do clima. A cobertura } \\
\text { vegetal nas restingas ocorrem em mosaico, e } \\
\text { encontra-se em praias, cordões arenosos, } \\
\text { dunas e depressões, apresentando, de acordo } \\
\text { com o estágio sucessional, estrato herbáceo, } \\
\text { arbustivos e arbóreo, este último mais }\end{array}$ & $\begin{array}{l}\text { São os ambientes de maior fragilidade } \\
\text { ambiental encontrados na área do } \\
\text { estudo, esses ambientes encontram-se } \\
\text { vastamente degradados. }\end{array}$ \\
\hline
\end{tabular}




\begin{tabular}{|c|c|c|}
\hline & $\begin{array}{l}\text { interiorizado; } \\
\text { X - duna: unidade geomorfológica de } \\
\text { constituição predominante arenosa, com } \\
\text { aparência de cômoro ou colina, produzida } \\
\text { pela ação dos ventos, situada no litoral ou no } \\
\text { interior do continente, podendo estar } \\
\text { recoberta, ou não, por vegetação }\end{array}$ & \\
\hline $\begin{array}{l}\text { Decreto Estadual } n^{\circ} \text {. } \\
\text { 12.620, de } 1995\end{array}$ & $\begin{array}{l}\text { Instituiu a Área de Proteção Ambiental } \\
\text { Genipabu. }\end{array}$ & $\begin{array}{l}\text { Apenas uma parte da área de estudo } \\
\text { encontra-se dentro dessa Área de } \\
\text { proteção, porém já a alguns anos a área } \\
\text { vem sendo degradada, principalmente } \\
\text { pela retirada da vegetação fixadora, o } \\
\text { que tem feito com que as dunas } \\
\text { avancem em direção as construções } \\
\text { mais próximas a ela. }\end{array}$ \\
\hline $\begin{array}{l}\text { Plano Diretor de } \\
\text { Desenvolvimento } \\
\text { Urbano - Extremoz } \\
\text { Lei }{ }^{\circ}{ }^{\circ}+493 / 2006 \\
\begin{array}{l}\text { Art. } 65, \$ 1^{\circ}-\text { Áreas } \\
\text { especiais }\end{array}\end{array}$ & $\begin{array}{l}\text { I - O Corredor dunas em dunas móveis, } \\
\text { julgadas de importância ambiental pelo } \\
\text { órgão competente, tendo por base estudos } \\
\text { técnicos aprovados e discutidos em } \\
\text { audiências públicas; } \\
\text { II - Os Manguezal em toda sua extensão; } \\
\text { III - a Mata Atlântica; } \\
\text { IV - a Mata ciliar; } \\
\text { V - Nascentes dos corpos d'água de } \\
\text { superfície, lagoas e demais mananciais; } \\
\text { VI - Sítios arqueológicos. }\end{array}$ & $\begin{array}{l}\text { Não foi identificada na área a efetiva } \\
\text { proteção total desses ecossistemas, } \\
\text { mostrando uma disparidade entre o que } \\
\text { está na legislação e a realidade. }\end{array}$ \\
\hline Lei $n^{0} 9.254$ de 2009 & $\begin{array}{l}\text { Dispõe sobre o zoneamento ecológico- } \\
\text { econômico da Área de Proteção Ambiental } \\
\text { Jenipabu - APAJ, nos municípios de } \\
\text { Extremoz e Natal. }\end{array}$ & $\begin{array}{l}\text { A Área de Proteção Ambiental } \\
\text { Genipabu está situada entre os } \\
\text { municípios de Natal e Extremoz, possui } \\
1.881 \text { hectares, tendo como ato de } \\
\text { criação o Decreto Estadual } \mathrm{n}^{\circ} \text {. } 12.620 \text {, } \\
\text { de } 17.05 .95 \text {, como já dito anteriormente } \\
\text { é uma área que também ocorrem } \\
\text { disparidades }\end{array}$ \\
\hline
\end{tabular}

Quadro 01. Enquadramento legal em relação às áreas protegidas do município de Extremoz-RN Fonte: elaboração dos autores com base nas legislações citadas.

Os conflitos ambientais legais neste estudo foram compreendidos através da sobreposição da ocupação do solo em áreas ambientalmente protegidas por lei. Desta forma, entende-se que as áreas protegidas ocupadas por atividades socioeconômicas são áreas de potencial conflito ambiental e que, por conseguinte, requerem maior cuidado no manejo e medidas mitigadoras no controle dos impactos ambientais.

Ao analisar o mapa na Figura 06, foi constatado a ocupação antrópica em 11,59\% (3,48 $\left.\mathrm{km}^{2}\right)$ das áreas protegidas, ficando até o presente momento, portanto, 88,4\% (26,54 $\left.\mathrm{km}^{2}\right)$ das áreas protegidas intactas. As classes de ocupação localizadas em áreas protegidas foram: atividades agropecuárias ao longo do rio Ceará-Mirim; carcinicultura próxima ao manguezal; áreas urbanizadas, sobretudo nas dunas fixas e móveis ao longo do litoral, e áreas em expansão urbana nas margens da lagoa de Extremoz. As áreas em vermelho, áreas de conflitos ambientais, são aquelas que merecem maior atenção quanto ao manejo e utilização de medidas mitigadoras que 
minimizem impactos ambientais negativos. As áreas vegetadas são aquelas que requerem maior atenção para preservação, dependendo para isso, de maior empenho do poder público na conservação dessas áreas. A Figura 6 apresenta o mapa de conflitos ambientais legais resultantes do interseccionamento das áreas ocupadas com as áreas protegidas.

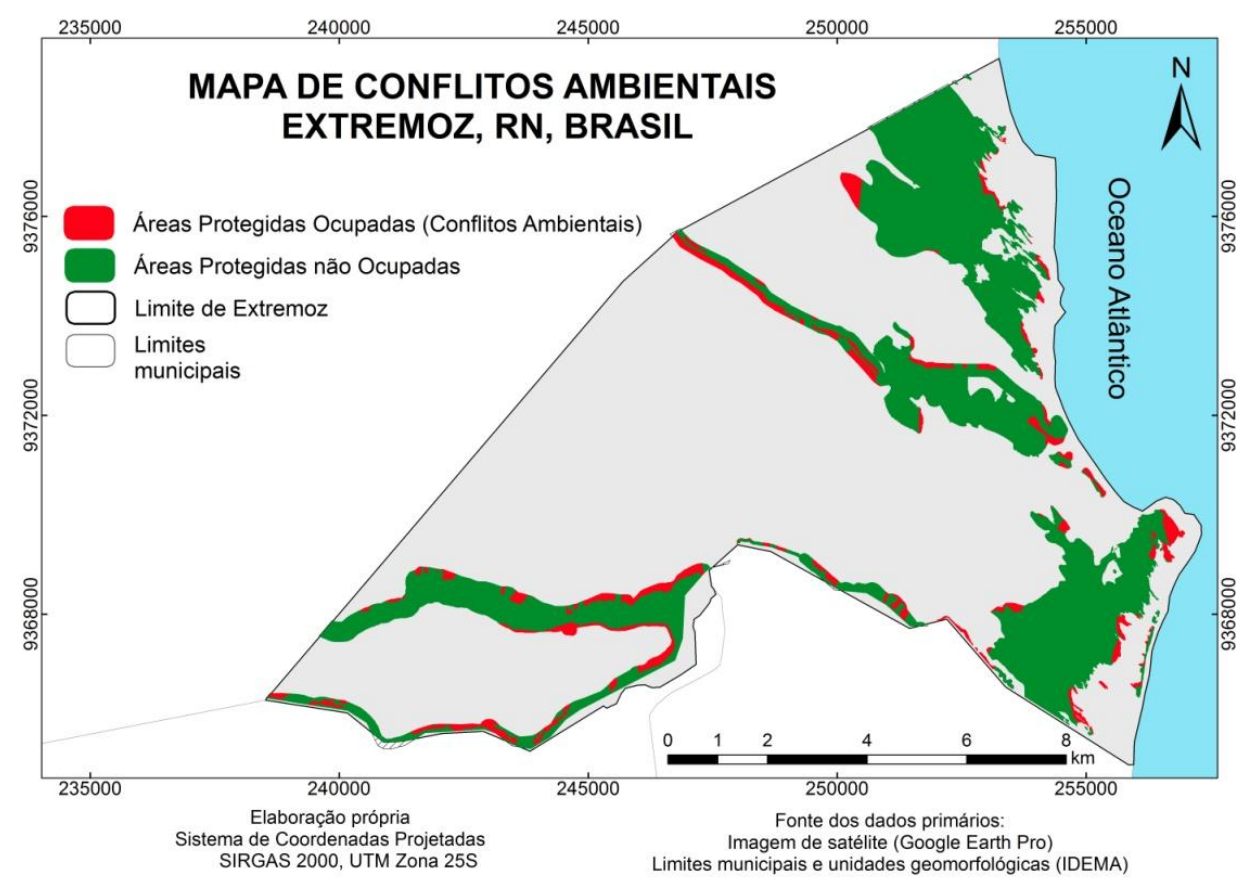

Figura 06. Mapa de conflitos ambientais legais em Extremoz-RN. Fonte: elaboração dos autores.

Os conflitos ambientais legais existentes na área em estudo são localizados pontualmente e, mesmo com uma área protegida por lei preservada em porção significativa, são observados pequenos conflitos em dunas móveis. A Figura 7 mostra a força e o avanço das dunas em área construída.

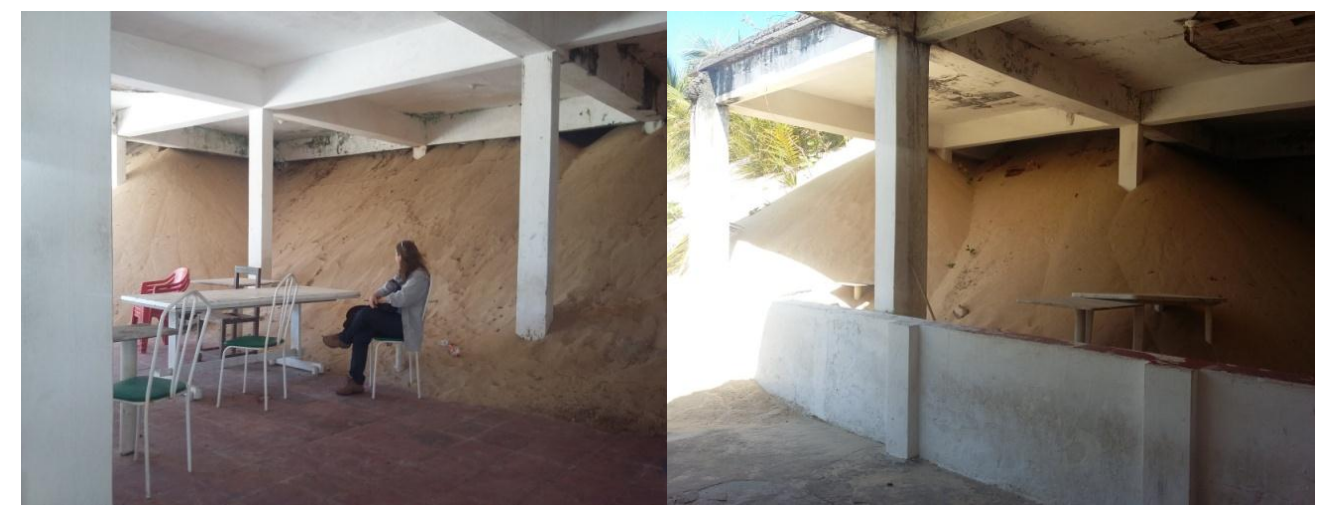

Figura 07. Avanço das dunas em estrutura beira-mar para turistas em Extremoz-RN. Fonte: pesquisa de campo. 
Nesse local, os proprietários removem a terra constantemente, contudo, os sedimentos das dunas avançam cada vez em maior escala e o local passou a não ser mais utilizado pelos proprietários. Salienta-se que ainda não foi realizada a remoção adequada da estrutura, ocasionando um conflito ambiental. Os moradores e comerciantes também improvisam barreiras com palhas de coqueiros para conter o avanço da duna (Figura 8).

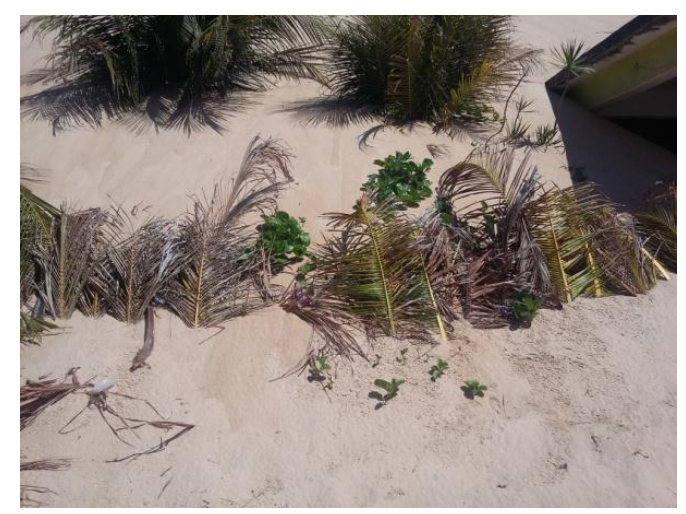

Figura 08. Barreira improvisada para conter o avanço da duna em Extremoz-RN. Fonte: pesquisa de campo.

As dunas são áreas protegidas, conforme citado no Quadro 01, enquadradas em âmbito federal na Resolução CONAMA nº 303, de 20 de março de 2002 que define APP. Também são protegidas por lei municipal, conforme o Plano Diretor de Desenvolvimento Urbano de Extremoz que coloca as dunas com relevante importância ambiental.

Foram observadas em campo outras construções sobre as dunas móveis, utilizadas por veranistas como segunda residência ou moradia definitiva (Figura 9). Esse tipo de ocupação se caracteriza como um conflito ambiental por estar localizada em área ambientalmente protegida por lei, conforme o Quadro 01 de enquadramento da legislação em Extremoz-RN. Na possibilidade de existência de construções não licenciadas nos órgãos competentes a situação torna-se também ilegal. Apesar da verificação de ocupação irregular nas dunas, a orla das praias de Extremoz permanecer ainda pouco ocupada, e boa parte ainda está preservada, conforme observado na Figura 10. 

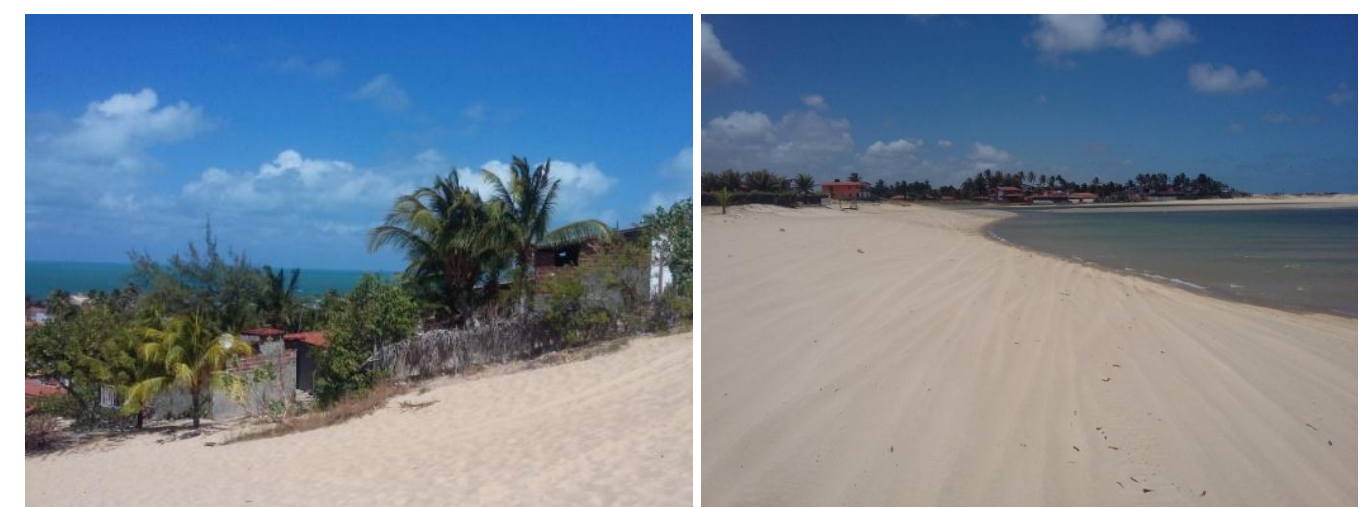

Figuras 09 e 10. Esquerda: ocupação de residências em dunas móveis em Extremoz-RN. Direita: Orla das praias do município de Extremoz ainda bastante preservada e com poucas ocupações. Fonte: pesquisa de campo.

Com a análise dos conflitos ambientais legais é possível compreender situações onde há confrontos de interesses em torno da utilização do meio ambiente, permitindo questionamentos, tais como: “A lei permite utilizar aquele ambiente?”, "Há áreas protegidas ocupadas? Quais são?”, “Qual o panorama das áreas protegidas que estão ocupadas?”.

A análise desses questionamentos para a área de estudo permitiu a compreensão dos usos e apropriação dos recursos naturais do local, localizando quais as áreas com maior tendência de tensão social (áreas de potencial conflito) e quais os locais que devem ser priorizados para aplicar ações de resolução desses conflitos.

\subsection{Impactos ambientais ocasionados pelas atividades antrópicas em Extremoz-RN}

Com o crescimento imobiliário, movido tanto pelos investimentos em conjuntos habitacionais, nas áreas de expansão urbana, quanto pelo aumento da atividade turística no litoral do município de Extremoz, ocorreu no local um considerável crescimento econômico nos últimos anos, como também o aumento de impactos ambientais. Desta forma, com a elaboração do mapa de ocupação e cobertura do solo relacionado com o mapa de unidades geomorfológicas, foi realizado um levantamento de campo com o objetivo de identificar os principais impactos ambientais correspondentes das diversas formas de ocupação do solo no município de Extremoz.

O primeiro ponto observado em campo foi nas margens da lagoa de Extremoz, em área de preservação permanente, de acordo com a resolução $1^{\circ}$ e $3^{\circ}$ da CONAMA n ${ }^{\circ} 004 / 85$. Nesta área, caracterizada como uma vertente com inclinação em torno de $20^{\circ}$ a $45^{\circ}$, a mata ciliar estava sendo desmatada para demarcação de lotes para construção civil (Figura 11). Além do impacto sobre a mata ciliar, há uma exposição do solo que, associada à inclinação da vertente, facilita a ocorrência dos processos erosivos. 


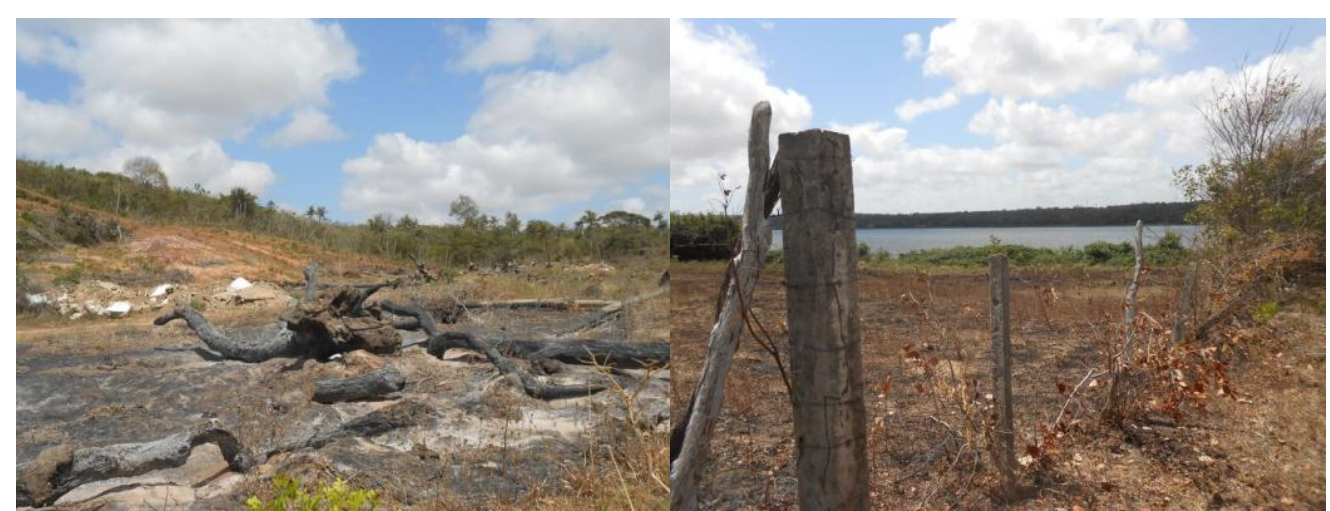

Figura 11. Queimada e desmatamento em área de mata ciliar na Lagoa de Extremoz. Fonte: pesquisa de campo.

É importante ressaltar que a retirada da mata ciliar e o aumento do escoamento superficial, tanto pela retirada da vegetação, quanto pela impermeabilização do solo pela construção civil, pode gerar problemas de assoreamento na lagoa, sendo essa muito importante para o abastecimento da população de Extremoz e para uma significativa parcela da população da capital do estado, Natal.

Outros pontos que merecem destaque relacionados ao crescimento imobiliário é a grande área desmatada ao Norte da área urbana de Extremoz, sobre o tabuleiro (definida no mapa de ocupação e cobertura do solo como área de expansão urbana) e a área de extração de areia, no contato do tabuleiro com as dunas fixas. O primeiro (Figura 12) se refere à grande área de vegetação de tabuleiro desmatada pela construção dos conjuntos habitacionais, causando impactos na fauna e flora da área, deixando o solo exposto às condições meteorológicas.

Vale salientar que não há uma instalação de um sistema de escoamento pluvial. No segundo caso (Figura 13), o desmatamento ocorre em uma vegetação mais densa em contato de unidades geomorfológicas, não sendo área de construção civil, mas uma área de empréstimo, onde o governo municipal libera para retirada de areia. Esta área também tem interferência na flora, pois pode-se identificar uma grande área desmatada, causando prejuízos ambientais como a redução das espécies vegetais e degradação dos solos.
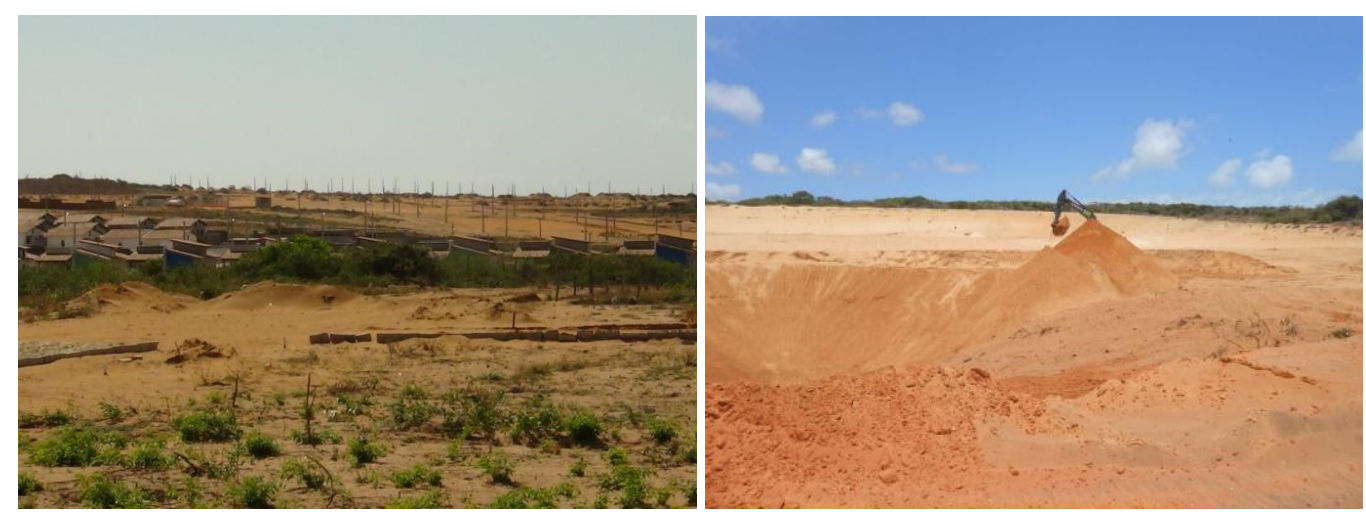
Figuras 12 e 13. Esquerda: Área de expansão urbana em Extremoz/RN. Direita: retirada de areia para construção civil em Extremoz/RN. Fonte: pesquisa de campo.

Segundo Araújo, Almeida e Guerra (2011, p. 64), “conforme a urbanização acontece, as mudanças na hidrologia de uma área são inevitáveis. Mudanças hidrológicas e hidráulicas ocorrem em resposta a limpeza do terreno, à terraplenagem e adição de superfície impermeáveis”. Logo, os problemas aqui expostos, evidenciados na Figura 12, contribuem para o aumento do escoamento superficial e, consequentemente, o aumento da carga de erosão e sedimentos carreados pelas águas superficiais.

Tratando da área de extração de areia (Figura 13), é importante relacionar com outra área mais antiga de extração do solo que, associada com o corte de estrada, provocou o processo de ravinamento pela exposição do solo às condições hidrológicas e pela instabilidade do mesmo, provocado pelo corte de estrada (Figura 14). É uma área localizada em uma das vertentes do rio Doce, sendo o limite Sul, entre o município de Extremoz e da capital Natal.

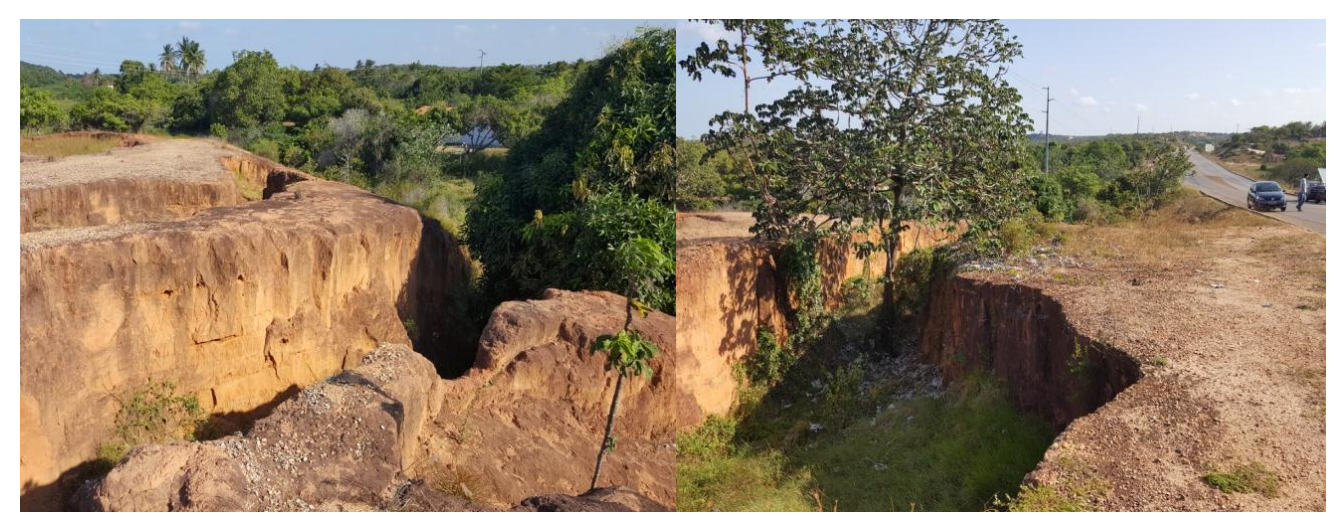

Figura 14. Ravinamentos em vertente do rio Doce, provocada pelo desmatamento associado ao corte de estrada em Extremoz. Fonte: pesquisa de campo.

É interessante destacar que ao longo do Rio Doce são encontradas atividades agropecuárias de subsistência, como também diversos processos erosivos nas suas vertentes, que podem ser ocasionados pela exposição do solo pela agropecuária, como também pela fraca estrutura dos solos, já que se tratam de neossolos quartzarênicos, que são solos bastante arenosos e profundos.

\section{CONSIDERAÇÕES FINAIS}

A partir do mapeamento da ocupação e cobertura do solo na área de estudo pode-se constatar características diferenciadas no município, como a relevante expressão espacial da agropecuária (23,9\% do território municipal), uma atividade econômica importante em conjunto 
com o turismo, além de grandes áreas de expansão de edificações nos tabuleiros costeiros, atreladas aos conjuntos habitacionais em construção, correspondendo à 17,2\% do território municipal. É importante considerar que no município existem ecossistemas que necessitam ser conservados, como o manguezal e a lagoa de Extremoz, pela sua importância na manutenção da biodiversidade e por serem fontes de recursos, como a pesca e a carcinicultura no Rio Ceará-Mirim ao longo do manguezal e a captação de água para abastecer parte da população de Extremoz e Natal.

Os conflitos ambientais legais foram compreendidos através da sobreposição da ocupação do solo em áreas ambientalmente protegidas por lei, nesse caso, a legislação ambiental federal que remete a APP (Conama n 303/2002) e o Plano Diretor do município que faz algumas considerações quanto à essas áreas. A partir dos resultados, observamos que apenas $11 \%$ das áreas protegidas estão ocupadas por atividades antrópicas, com destaque para as atividades agropecuárias, ao longo do Rio Ceará-Mirim, a carcinicultura, próxima ao manguezal, as áreas urbanizadas e áreas em expansão de edificação nas margens da lagoa de Extremoz. Os conflitos ambientais mais evidentes foram presenciados em dunas móveis, enquadrada como área protegida por lei.

Quanto aos impactos ambientais correspondentes as diversas formas de ocupação do solo no município de Extremoz, destacamos quatro pontos: Retirada de mata ciliar com desmatamento e queima da vegetação para demarcação de lotes para construção civil, com possibilidade de ocorrência de processos erosivos e assoreamento às margens da lagoa de Extremoz; Área desmatada ao Norte da área urbana de Extremoz sobre o tabuleiro (definida aqui como área de expansão urbana), para construção de novos conjuntos habitacionais; Área de extração de areia para empréstimo, no contato do tabuleiro com as dunas fixas, contribuindo para a redução das espécies vegetais e degradação dos solos; e, Extração do solo associada com um corte de estrada que gerou um processo de ravinamento, esta área se localiza em uma das vertentes do rio Doce, sendo o limite Sul entre o município de Extremoz e da capital Natal.

Nesse contexto, a análise dos conflitos legais em áreas protegidas e os impactos ambientais na área em estudo possibilita encaminhamentos para o planejamento integrado através do Plano Diretor da cidade e para a gestão ambiental, pensando na preservação e conservação ambiental.

\section{REFERÊNCIAS}

AGUIAR, L. S. Dinâmica ambiental da planície de deflação do litoral de Extremoz / RN e influências das normativas legais no processo de organização territorial. Dissertação de Mestrado apresentada ao Programa de Pós-Graduação e Pesquisa em Geografia da UFRN, 2013.

AMARO, V. E.; SANTOS, M. S. T.; SOUTO, M. V. S. Geotecnologias ao monitoramento costeiro: sensoriamento remoto e geodésia de precisão. Natal: Do Autor, 2012. 
ARAÚJO, G. H. S.; ALMEIDA, J. R.; GUERRA, A. J. T. Gestão Ambiental de Áreas Degradadas. $7^{\circ} \mathrm{Ed}$. Rio de Janeiro: Bertrand Brasil, 2011.

ATLAS DO DESENVOLVIMENTO HUMANO. Perfil do município de Extremoz, RN. Disponível em: <http://www.atlasbrasil.org.br/2013/pt/perfil_m/extremoz_rn>. Acesso em: 27/11/2015.

BRASIL. Constituição da República Federativa do Brasil: artigo 225. Senado Federal. Brasília: Centro Gráfico, 1988.

CONSELHO NACIONAL DO MEIO AMBIENTE (CONAMA). Resolução $\mathbf{n}^{\mathbf{0}}$ 303, de 20 de março de 2002. Dispõe sobre parâmetros, definições e limites de Áreas de Preservação Permanente. Disponível em:> http://www.mma.gov.br/port/conama/res/res02/res30302.html>. Acesso em: 10/10/2015.

DICIONÁRIO PORTUGUÊS. Definição de "aração". Disponível em: <http://dicionarioportugues.org/pt/aracao>. Acesso em: 03/02/2016.

. Definição de “gradagem”. Disponível em: <http://dicionarioportugues.org/pt/gradagem>. Acesso em: 03/02/2016.

ECOPLAM consultoria ambiental. RIMA do Polo de Turismo Ecológico e Aventura de Pitangui e Jacumã. Natal/RN, 2006. Disponível em: <http://200.149.240.140/rimas/rimas.asp>. Acesso em: 19/09/2015.

EMPRESA DE PESQUISA AGROPECUÁRIA DO RIO GRANDE DO NORTE (EMPARN). Meteorologia. Monitoramento pluviométrico. 2015. Disponível em: <http://www.emparn.rn.gov.br/>. Acesso em: 01/09/2015.

EXTREMOZ. Plano Diretor de Desenvolvimento Urbano. Lei n ${ }^{\circ} 493 / 2006$ : Art. 65, $\S 1^{\circ}$ - Áreas especiais. $\mathrm{em}:<$ http://www.cidades.gov.br/images/stories/ArquivosSNPU/RedeAvaliacao/Extremoz_PlanoDiretorR N.pdf >. Acesso em: 10/10/2015.

GOVERNO DO ESTADO DO RIO GRANDE DO NORTE. Decreto $\mathbf{n}^{\mathbf{0}} \mathbf{1 2 . 6 2 0}$, de 17 de maio de 1995. Cria a Área de Proteção Ambiental (APA) Genipabu, nos Municípios de Extremoz e Natal e dá outras providências. Disponível em: http://adcon.rn.gov.br/ACERVO/idema/DOC/DOC000000000033843.PDF>. Acesso em: $10 / 10 / 2015$.

Lei $n^{0}$ 9.254 de 2009. Dispõe sobre o Zoneamento Ecológico Econômico da Área de Proteção Ambiental Jenipabu - APAJ, nos Municípios de Extremoz e Natal, criada pelo Decreto n. ${ }^{\circ}$ 12.620, de 17 de maio de 1995, e dá outras providências. Disponível em: < http://adcon.rn.gov.br/ACERVO/idema/DOC/DOC000000000033846.PDF>. Acesso em: 10/10/2015.

INSTITUTO BRASILEIRO DE GEOGRAFIA E ESTATÍSTICA (IBGE). Censo Agropecuário 2006. Extremoz, Rio Grande do Norte. Disponível em: <http://www.cidades.ibge.gov.br/xtras/temas.php?lang=\&codmun=240360\&idtema=3\&search=riogrande-do-norte|extremoz|censo-agropecuario-2006>. Acesso em: 05/10/2015. 
Censo Demográfico 2010. Disponível em:

<http://cidades.ibge.gov.br/xtras/perfil.php?codmun=240360>. Acesso em: 05/10/2015.

INSTITUTO DE DESENVOLVIMENTO SUSTENTÁVEL E MEIO AMBIENTE DO RIO GRANDE DO NORTE (IDEMA). Perfil do seu município: Extremoz, RN. Natal: IDEMA, 2013.

INSTITUTO NACIONAL DE METEOROLOGIA (INMET). BDMEP - Banco de Dados Meteorológicos para Ensino e Pesquisa. 2015. Disponível em: <http://www.inmet.gov.br/projetos/rede/pesquisa/>. Acesso em: 01/09/2015.

NASCIMENTO, L. K. S. Geografia, turismo e meio ambiente: uma nova face do litoral dos municípios de Extremoz e Ceará-Mirim/RN. Dissertação de Mestrado apresentada ao Programa de Pós-Graduação e Pesquisa em Geografia da UFRN, 2008.

ROSA, R. Geotecnologias na geografia aplicada. Revista do Departamento de Geografia, n. 16. São Paulo: 2005.

SALES, V. C. Geografia, sistemas e análise ambiental: abordagem crítica. GEOUSP - Espaço e Tempo, nº 16. São Paulo: 2004.

SECRETARIA DO MEIO AMBIENTE E DOS RECURSOS HÍDRICOS DO RIO GRANDE DO NORTE (SEMARH). Plano Estadual de Recursos Hídricos. Natal: SEMARH, 2008.

TRICART, Jean. Ecodinâmica. Rio de Janeiro: IBGE, 1977.

\section{AGRADECIMENTOS}

À Coordenação de Aperfeiçoamento de Pessoal de Nível Superior e ao Programa de PósGraduação e Pesquisa em Geografia da UFRN pelo auxílio financeiro e logístico.

Recebido em: 31/12/2017

Aceito para publicação em: 01/06/2018 